\title{
Isolation of Lactic Acid Bacteria with Cholesterol-Lowering Activity from Digestive Tracts of Indonesian Native Chickens
}

\author{
H. Julendraa ${ }^{a}$ A. E. Suryani ${ }^{\text {** }}$, L. Istiqomah ${ }^{\mathrm{a}}$, E. Damayantia ${ }^{\mathrm{a}}$ M. Anwar ${ }^{\mathrm{a}}$, \& N. Fitriani ${ }^{\mathrm{b}}$ \\ aResearch Center for Natural Product Technology (BPTBA), Indonesian Institute of Sciences (LIPI) \\ Gading, Playen, Gunungkidul DI. Yogyakarta, Indonesia \\ bStudent of Department of Biology, Faculty of Mathematics and Natural Sciences, Sebelas Maret University (UNS) \\ Jalan Ir. Sutami No. 36A, Jebres, Kota Surakarta, Jawa Tengah 57126, Indonesia \\ (Received 29-09-2016; Reviewed 24-11-2016; Accepted 06-03-2017)
}

\begin{abstract}
The aim of the study was to identify the cholesterol-lowering activity of indigenous lactic acid bacteria isolated from the small intestine, cecum, and colon of Indonesian native chickens and evaluated for bile salt hydrolase (BSH) activity in vitro by using MRS media added taurodeoxycholic acid (TDCA) and $\mathrm{CaCl}_{2}$. The quantitative measurement of cholesterol-lowering activity of LAB was investigated by using soluble cholesterol containing MRS broth $(100 \mu \mathrm{g} / \mathrm{mL}$ of cholesterin) and incubated at $37^{\circ} \mathrm{C}$ for $48 \mathrm{~h}$. Cholesterol content in supernatant was analyzed using microplate reader. The highest percentage of cholesterol reduction found in isolates from colon of native chicken with the value of $17.43 \%$ and identified as Lactobacillus plantarum. Based on phylogenetic tree analysis, this isolate was closely related to L. plantarum strain LGFCP4 (accession number KM199683.1) isolated from GIT of Guinea fowl from India. It could be concluded that L. plantarum AKK-30 had cholesterol-lowering activity.
\end{abstract}

Keywords: lactic acid bacteria (LAB), cholesterol, bile salt hydrolase (BSH), native chicken

\section{ABSTRAK}

Penelitian ini bertujuan untuk mengidentifikasi aktivitas penurunan kolesterol oleh bakteri asam laktat indigenous. Bakteri asam laktat (BAL) diisolasi dari usus halus, sekum dan kolon ayam kampung Indonesia dan dievaluasi terhadap aktivitas hidrolase garam empedu secara in vitro dengan menggunakan media MRS yang ditambahkan asam taurodeoxycholic (TDCA) dan $\mathrm{CaCl}_{2}$. Pengukuran secara kuantitatif aktivitas penurunan kolesterol oleh BAL dilakukan dengan menggunakan MRS Broth yang mengandung kolesterol terlarut $(100 \mu \mathrm{g} / \mathrm{mL}$ cholesterin) dan diinkubasikan pada suhu $37^{\circ} \mathrm{C}$ selama 48 jam. Kolesterol yang terkandung di dalam supernatan dianalisis menggunakan microplate reader. Persentase penurunan kolesterol tertinggi dengan nilai $17.43 \%$ ditemukan pada isolat yang berasal dari kolon ayam kampung dan diidentifikasi sebagai Lactobacillus plantarum. Berdasarkan analisis pohon filogeni, isolat tersebut memiliki kekerabatan yang dekat dengan L. plantarum strain LGFCP4 (accession number KM199683.1) yang diisolasi dari saluran pencernaan ayam mutiara asal India. Dapat disimpulkan bahwa L. plantarum AKK-30 memiliki aktivitas menurunkan kolesterol.

Kata kunci: bakteri asam laktat (BAL), kolesterol, hidrolase garam empedu, ayam kampung

\section{INTRODUCTION}

Cholesterol contained in broiler meat without skin is around $133-202 \mathrm{mg} / 100 \mathrm{~g}$ of dry matter (DM) basis and in the whole meat is around $261-407 \mathrm{mg} / 100 \mathrm{~g}$ of DM (Ismoyowati \& Widyastuti, 2003). Native chicken

*Corresponding author:

E-mail: deyan02@gmail.com has the ability to suppress the levels of cholesterol in meat; it is probably due to activity of lactic acid bacteria that live in the intestines. The cholesterol-lowering mechanism for some types of beneficial bacteria including lactic acid bacteria that thought to have the ability to metabolize cholesterol from food in the intestines, so it was not absorbed by the gut (de Ross \& Katan, 2000). According to Ooi \& Liong (2010), an alternative method to reduce levels of cholesterol and triglycerides in poultry meat was the use of lactic acid bacteria as probiotics. 
Bile-salt hydrolase (BSH) are enzyme deconjugates bile acid into glycine or taurine from the steroid moiety, producing free bile salts. Deconjugated bile salt is not easy to be absorbed by small intestine then it is excreted in feces that eventually reduces the number of bile acids returned to the liver. BSH activity is detected in some strains related to the gastrointestinal tract (GIT), representing several species of LAB (Bifidobacterium and Lactobacillus) indigenous of the digestive tract (Kumar et al., 2012). However, probiotics derived from endogenous bacteria of chicken is still inefficient. Probiotics that do not originate from the indigenous bacteria when entering through the digestive tract will be damaged before it reaches the small intestine, therefore the use of probiotic from indigenous bacteria are expected to be more tolerant to change in $\mathrm{pH}$, temperature, and enzyme activity of digestive tracts.

Based on research conducted by Agaliya \& Jeevaratnam (2012) studying cholesterol lowering effect of 8 lactobacilli, the strain L. plantarum JJ18 showed a higher cholesterol removal capacity from media and tolerance towards acid and bile. Cenesiz et al. (2008) also reported that supplementation of $\mathrm{LAB}$ as probiotic in broiler birds significantly $(\mathrm{P} \leq 0.05)$ reduced total cholesterol serum level.

The aim of the study was to identify the cholesterol-lowering activity of indigenous lactic acid bacteria isolated from the small intestine, cecum, and colon of Indonesian native chickens and evaluated for bile salt hydrolase (BSH) activity in vitro by using MRS media added taurodeoxycholic acid (TDCA) and $\mathrm{CaCl}_{2}$. This LAB will be used for chicken as a feed additive to reduce the cholesterol level in poultry meat.

\section{MATERIALS AND METHODS}

\section{Isolation and Identification of Lactic Acid Bacteria}

Strains of LAB were collected from digestive tract of Indonesian native chicken (Ayam Kampung) according to Torshizi et al. (2008) method. Small intestine, cecum, and colon were cut, and the contents of lumen were taken and then diluted in $\mathrm{NaCl}$ solution (Merck) $0.85 \%$ up to 105 dilutions. de Mann Rogosa Sharpe (MRS) Agar media (Oxoid) with pH 6.2 and $0.2 \%$ $\mathrm{CaCO} 3$ (Merck) was plated and incubated at $37{ }^{\circ} \mathrm{C}$ for $24 \mathrm{~h}$ with the addition of each serial dilution. The LAB colonies were identified by clearing zone appearance. LAB characterization procedures consisted of morphology, Gram staining, catalase, gas production, and motility tests according to Krieg et al. (2010). API 50 CHL kit (bioMērieux) were used to observe biochemical identification of the selected LAB. The observation data were determined by API web software (bioMērieux).

The identification of LAB was also confirmed using alignment of 16S rRNA gene sequence available in GenBank. DNA genome from LAB was isolated according to PeqGOLD Bacterial DNA kit. DNA was amplified using primer sequences of $27 \mathrm{f}$ (5'-AGAGTTTGATCCTGGCTCAG-3') and 1492r (5'-GGTTACCTTGTTACGACTT-3') (Gong et al., 2007). Sequencing of $16 S$ rRNA gene was conducted by First BASE laboratories (Singapore). Data of DNA sequence was edited by FinchTV program and contiq with BioEdit, and kept in FASTA format. The sequence result was analyzed by basic local alignment search tool (BLAST) program by accessing data in NCBI. Phylogenetic analysis was performed by comparing several sequences with high similarity in BLAST result. Statistical method was using Maximum-likelihood. Stability of grouping was measured using 1000 bootstrap replicates. Phylogenetic tree was performed by MEGA5 program (Cobos et al., 2011).

LAB isolates were kept at $-80{ }^{\circ} \mathrm{C}$ in MRS broth consisting of $15 \%$ (v/v) glycerol. An MRS-agar plate was streaked from the frozen stock to ensure purity for any assay.

\section{Bile Salt Hydrolase Activity}

Prior to determining the ability of LAB in lowering of cholesterol, the selected isolates were tested to make sure whether they have bile salt hydrolase (BSH) activity. The test was conducted by impregnation around sterilized paper disks (Oxoid) on the MRS agar plates added with sodium salt of taurodeoxycholic acid $0.5 \%$ (w/v) (TDCA, Sigma, USA), and $0.37 \mathrm{~g} / \mathrm{L} \mathrm{CaCl}_{2}$ (Merck). Plates were incubated in anaerobic condition for $72 \mathrm{~h}$ at $37^{\circ} \mathrm{C}$, and the precipitation zones diameter around the disks was calculated (Lim et al., 2004; Sirilun et al., 2010).

\section{Cholesterol-lowering Activity}

Cholesterol (C75209, Sigma) was dissolved in Tween 80, then added to MRS at the final concentration of $100 \mu \mathrm{g} / \mathrm{mL}$. One percent of LAB in the broths were anaerobically by giving $\mathrm{CO}_{2}$ gas into the tube and incubated for $24 \mathrm{~h}$ at $37^{\circ} \mathrm{C}$. After incubation, the broths containing $\mathrm{LAB}$ were centrifuged at $4000 \mathrm{rpm}$ for $10 \mathrm{~min}$ at $4{ }^{\circ} \mathrm{C}$ (Centofriger ${ }^{\circledR}$ BL II, Selecta) and the supernatants were collected. Cholesterol concentrations in supernatants were determined using Tomaro-Duchesnau et al. (2014) method. Briefly, $500 \mu \mathrm{L}$ of $33 \%(w / v) \mathrm{KOH}$ and one $\mathrm{mL}$ absolute ethanol were added to $500 \mu \mathrm{L}$ of the supernatant. The solutions were then vortexed and incubated at $37{ }^{\circ} \mathrm{C}$ for 15 min followed by cooling to room temperature. For phase separation, one $\mathrm{mL}$ of aquadest and $1.5 \mathrm{~mL}$ of hexanes were added to the solutions and vortexed. The phases were then allowed to separate at room temperature. Subsequently, $500 \mu \mathrm{L}$ of the hexane layer was transferred into a glass tube, and the solvent was evaporated by using nitrogen gas. Once dried, one $\mathrm{mL}$ of $50 \mathrm{mg} / \mathrm{dL}$ o-phthalaldehyde reagent prepared in acetic acid was added, and the samples were mixed. Following mixing, $250 \mu \mathrm{L}$ of concentrated $\mathrm{H}_{2} \mathrm{SO}_{4}$ was added to each tube, and the solutions were vortexed then incubated for $20 \mathrm{~min}$ at room temperature. The absorbance was read at $570 \mathrm{~nm}$ using a microplate reader (Thermo Scientific). A standard curve of absorbance versus cholesterol concentrations was generated using the cholesterol concentrations: 0, 4, 8, 12, 16, 24, 32, 40, $52,64,128,256 \mu \mathrm{g} / \mathrm{mL}$ cholesterol in MRS (R2=0.998). Cholesterol lowering effect was calculated following the equation: 
Cholesterol lowering effect $=\left(C-C^{\prime}\right) / C$,

where the concentrations of cholesterol existing in the supernatants of uninoculated and inoculated were C and $C^{\prime}$ (Guo et al., 2011). Cholesterol-lowering percentage by each Lactobacillus strain was also calculated as follow:

$\%$ Cholesterol-lowering $=[($ cholesterol-lowering $(\mu \mathrm{g} /$ $\mathrm{mL}) /$ cholesterol $(\mu \mathrm{g} / \mathrm{mL})] \times 100 \%$

\section{RESULTS}

\section{Isolation of Lactic Acid Bacteria Candidates from Chicken's Gastrointestinal Tract}

Lactic acid bacteria isolation from chicken's digestive tract was successful in selecting 26 (8 isolates derived from the small intestine, eight isolates from the cecum, and ten isolates from the colon). The selected LAB had a single colony, and clear zone appearance on MRS-agar supplemented with $0.2 \% \mathrm{CaCO}_{3}$. These isolates did not have catalase, did not produce gas on Glucose Yeast Peptone (GYP) medium, non-motile on Sucrose Yeast Peptone (SYP) medium, Gram-positive and had coccus and rod shape.

\section{Characterization of Selected Lactic Acid Bacteria}

Table 1 showed that 26 isolates characterized as $\mathrm{LAB}$ produced negative results on catalase test. Observations of 26 isolates of LAB by staining showed that all isolates were Gram-positive (Damayanti et al., 2012). Motility test indicated that all of isolates had nonmotile properties showing no movement that resembles a vine-propagation besides the needle puncture area and there was no cloud formation at SYP medium.

\section{Bile Salt Hydrolase Activity}

For 26 isolates tested, all have the precipitation zones (Figure 1) with different diameters (Table 2). Isolates with the largest diameter values were isolated from chicken intestine (AKU-4), while isolates that have the smallest diameter values were isolated from chicken colon (AKK-21).

\section{In vitro Test for Cholesterol-lowering Activity}

The results showed that the ten isolates of $\mathrm{LAB}$ have the action for lowering cholesterol levels (Table 3). The activity of LAB to decrease cholesterol varied in a range of $16.6-34.4 \mu \mathrm{g} / \mathrm{mL}$. The highest activity was shown by AKK-30 with percentage of $17.43 \%$ followed by AKU-4 at $15.24 \%$, and AKS-16 at $15.02 \%$, while the lowest cholesterol reduction rate present in isolates AKS-19 with $8.41 \%$ compared to control.

\section{Identification of Selected LAB with the Highest Cholesterol-lowering Activity}

The chosen lab isolate was identified based on biochemical procedures by using API 50 CHL kit (bioMer- ieux) as shown in Table 4 . In biochemical identification, AKK-30 isolate was identified as Lactobacillus plantarum (92.3\% of similarity), and 27 types of carbohydrates were able to be fermented. Based on 16s rRNA sequences analysis, AKK-30 was identified as L. plantarum.

Tabel 1. Characteristics of lactic acid bacteria isolated from digestive tracts of native chicken

\begin{tabular}{|c|c|c|c|c|c|}
\hline Isolate & Morphology & $\begin{array}{c}\text { Gram } \\
\text { staining }\end{array}$ & $\begin{array}{c}\text { Catalase } \\
\text { test }\end{array}$ & $\begin{array}{c}\text { Motility } \\
\text { test }\end{array}$ & $\begin{array}{c}\text { Gas pro- } \\
\text { duction } \\
\text { assay }\end{array}$ \\
\hline \multicolumn{6}{|c|}{ Intestine of native chicken } \\
\hline AK U 1 & Coccus & + & - & - & - \\
\hline AK U 2 & Short rod & + & - & - & - \\
\hline AK U 3 & Coccus & + & - & - & - \\
\hline AK U 4 & Short rod & + & - & - & - \\
\hline AK U 5 & Short rod & + & - & - & - \\
\hline AK U 6 & Coccus & + & - & - & - \\
\hline AK U 7 & Coccus & + & - & - & - \\
\hline AK U 8 & Coccus & + & - & - & - \\
\hline \multicolumn{6}{|c|}{ Caecum of native chicken } \\
\hline AK S 9 & Coccus & + & - & - & - \\
\hline AK S 10 & Short rod & + & - & - & - \\
\hline AK S 11 & Short rod & + & - & - & - \\
\hline AK S 14 & Coccus & + & - & - & - \\
\hline AK S 16 & Short rod & + & - & - & - \\
\hline AK S 17 & Short rod & + & - & - & - \\
\hline AK S 18 & Short rod & + & - & - & - \\
\hline AK S 19 & Coccus & + & - & - & - \\
\hline \multicolumn{6}{|c|}{ Colon of native chicken } \\
\hline AK K 21 & Short rod & + & - & - & - \\
\hline AK K 22 & Short rod & + & - & - & - \\
\hline AK K 23 & Coccus & + & - & - & - \\
\hline AK K 24 & Short rod & + & - & - & - \\
\hline AK K 25 & Short rod & + & - & - & - \\
\hline AK K 27 & Coccus & + & - & - & - \\
\hline AK K 29 & Short rod & + & - & - & - \\
\hline AK K 30 & Short rod & + & - & - & - \\
\hline AK K 31 & Short rod & + & - & - & - \\
\hline AK K 32 & Long rod & + & - & - & - \\
\hline
\end{tabular}

Note: $(-)=$ Negative reaction, $(+)=$ Positive reaction .

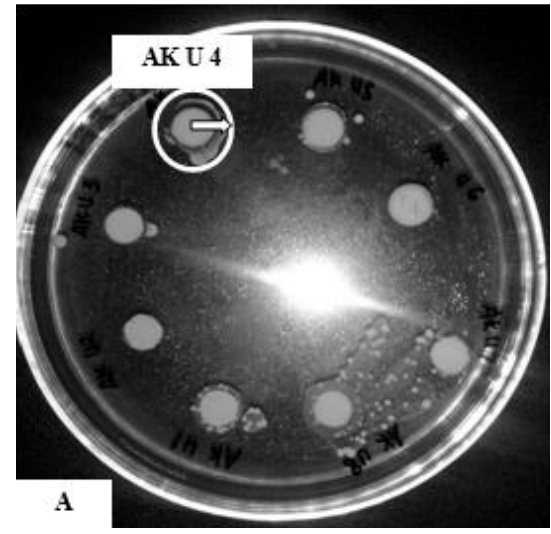

Figure 1. Precipitation zone of AKU-4 isolate 
Table 2. Diameter precipitation zone of 26 isolates lactic acid bacteria from digestive tracts of native chicken

\begin{tabular}{|c|c|c|c|}
\hline \multirow{2}{*}{ Isolate } & \multicolumn{3}{|c|}{ Diameter zone of precipitation $(\mathrm{mm})$} \\
\hline & control & $\mathrm{d} 1$ & $\mathrm{~d} 2$ \\
\hline \multicolumn{4}{|l|}{ Intestine } \\
\hline AK U 1 & 6 & 9.9 & 9.9 \\
\hline AK U 2 & 6 & 6.1 & 4.6 \\
\hline AKU 3 & 6 & 7 & 8.3 \\
\hline AK U 4 & 6 & 13.4 & 10.5 \\
\hline AKU 5 & 6 & 9.1 & 8.3 \\
\hline AM 6 & 6 & 8 & 8 \\
\hline I 7 & 6 & 7.6 & 7.6 \\
\hline ME 8 & 6 & 6.7 & 8.9 \\
\hline \multicolumn{4}{|l|}{ Caecum } \\
\hline AK Graduate 9 & 6 & 11 & 9.2 \\
\hline AK S 10 & 6 & 7.1 & 7.1 \\
\hline AK S 11 & 6 & 7.3 & 6.7 \\
\hline AK S 14 & 6 & 7.4 & 7.4 \\
\hline AK Graduate 16 & 6 & 8.1 & 10.4 \\
\hline AKS 610.910 .915 & & & \\
\hline AKS 67.67 .416 & & & \\
\hline AK S 19 & 6 & 9 & 9.8 \\
\hline \multicolumn{4}{|l|}{ Colon } \\
\hline AK K 21 & 6 & 5 & 6.3 \\
\hline AK K 67.77 .219 & & & \\
\hline AK K 23 & 6 & 6.5 & 6.3 \\
\hline AK K 67.26 .821 & & & \\
\hline AK K 66.45 .722 & & & \\
\hline AK K 65.45 .423 & & & \\
\hline AK K 66.46 .924 & & & \\
\hline AK K 610.28 .625 & & & \\
\hline AK K 67.36 .226 & & & \\
\hline AK K 32 & 6 & 6.8 & 6.8 \\
\hline
\end{tabular}

\section{DISCUSSION}

\section{Isolation of Lactic Acid Bacteria Candidates from Chicken's Gastrointestinal Tract}

Supplementation of $\mathrm{CaCO}_{3}$ into the media was intended to obtain early estimation colonies of LAB with the clear zone presence appeared after the incubation period. Calcium carbonate reacted with the lactic acid produced by LAB thus forming Ca-lactate acids and identified by clear zone around the colonies on media (Harimurti et al., 2005). According to Jannah et al. (2014), microbiota diversity and abundance varied at a particular location along the gastrointestinal tract, the number of the microbiota declined in less favorable condition for bacterial growth. The presence of microorganisms in the poultry's digestive tract due to the interaction of bacteria with the environment that entry by feeding. Differences age of the chicken also gave differences in the amount and type of bacteria present in the gastrointestinal tract. Heravi et al. (2011) also stated that the bacteria isolated from chicken digestive was Lactobacillus which had specification such as positive Gram stain, catalase negative reactions, and form of bacillus and the amplification of $16 \mathrm{~s}$ rRNA fragments $(0.24 \mathrm{kbp})$ using specific primers assured that all isolated bacteria belongs to the genus of Lactobacillus.

\section{Characterization of Selected Lactic Acid Bacteria}

Negative results on catalase test that were found in 26 isolates indicated by the formation of oxygen after $\mathrm{H}_{2} \mathrm{O}_{2}$ addition. This lead to accordance with Adams \& Nout (2001) who stated that LAB had negative catalase activity. The gas production assay from all isolates showed negative result hence the isolates were homofermentative (Shazali et al., 2014). Based on biochemical point of view, LAB consist of both homofermenters, yielding mainly lactic acid, and heterofermenters, which, apart from lactic acid, produce a large variety of fermentation metabolites such as acetic acid, carbon dioxide, ethanol, and formic acid (Kleerebezem \& Hugenholtz, 2003).

In this research 26 isolates of LAB included in the class of gram-positive bacteria when it formed purple color under a microscope. Negative results from motility test showed that the lactic acid bacteria had no flagella for movement.

\section{Bile Salt Hydrolase activity}

Precipitation zone that was formed in BSH enzyme activity was caused by the deposition of cholesterol as a bile acids constituent that has been conjugated (Sirilun et al., 2010). In the qualitative test of BSH enzyme activity, sodium salt taurodeoxycholic acts as a substrate that will be conjugated by $\mathrm{BSH}$ from lactic acid bacteria, while the addition of $\mathrm{CaCl}_{2}$ ion intended to optimize $\mathrm{BSH}$ enzyme activity. Bile salt hydrolase is produced by lactic acid bacteria, these enzymes can produce conjugated bile acids in the form of free cholic acids that are less absorbed by the intestine. A qualitative test intended to determine the activities of bile salt hydrolase that produced by lactic acid bacteria in conjugate sodium salt taurodeoxycholic acid were added in the media. If detected positive for BSH enzyme activity, precipitation zone will appear around the paper disk that contains lactic acid bacteria (Lim et al., 2004).

Table 3. Cholesterol value from in vitro test using ELISA Microplate Reader (ppb)

\begin{tabular}{ccccccccccc}
\hline AK U 1 & AK U 4 & AK U 5 & AK U 6 & AK U 8 & AK S 9 & AK S 16 & AKS 17 & AK S 19 & AK K 30 & CONTROL \\
\hline 183.8 & 171.2 & 166.4 & 185.0 & 179.0 & 175.7 & 169.6 & 162.5 & 198.1 & 166.2 & 207.8 \\
175.1 & 168.9 & 185.3 & 170.4 & 178.8 & 180.7 & 164.2 & 170.2 & 173.3 & 164.0 & 194.0 \\
177.6 & 161.7 & 174.2 & 170.6 & 170.4 & 173.6 & 169.3 & 173.2 & 170.8 & 158.6 & 190.2 \\
\hline
\end{tabular}


Table 4. Fermentation of 49 types of carbohydrate based test identification using API KIT 50 CHL for AKK-30

\begin{tabular}{|c|c|c|c|c|c|}
\hline No. & Type of carbohydrates & AKK- 30 & No & Type of carbohydrates & AKK-30 \\
\hline 0 & Temoin & - & 25 & Esculine & + \\
\hline 1 & Glycerol & + & 26 & Salicin & + \\
\hline 2 & Erythritol & - & 27 & D-Cellibiose & + \\
\hline 3 & D-arabinose & - & 28 & D-Maltose & + \\
\hline 4 & L-arabinose & + & 29 & D-Lactose & + \\
\hline 5 & D-ribose & + & 30 & D-Melibiose & + \\
\hline 6 & D-xylose & - & 31 & D-Sacharose & + \\
\hline 7 & L-xylose & - & 32 & D-Trehalose & + \\
\hline 8 & D-adonitol & - & 33 & Inulin & - \\
\hline 9 & Methyl- $\beta$ D-xylopyranoside & - & 34 & D-Melezitose & + \\
\hline 10 & D-galactose & + & 35 & D-Raffinose & + \\
\hline 11 & D-glucose & + & 36 & Amidon & - \\
\hline 12 & D-fructose & + & 37 & Glycogen & - \\
\hline 13 & D-mannose & + & 38 & Xylitol & - \\
\hline 14 & L-sorbose & - & 39 & Gentibiose & - \\
\hline 15 & L-rhamnose & + & 40 & D-Turanose & + \\
\hline 16 & Dulcitol & - & 41 & D-Lyxose & - \\
\hline 17 & Inositol & - & 42 & D-Tagatose & + \\
\hline 18 & D-mannitol & + & 43 & D-Fucose & - \\
\hline 19 & D-sorbitol & + & 44 & L-Fucose & - \\
\hline 20 & Methyl- $\alpha$ D-mannopyranoside & + & 45 & D-arabitol & - \\
\hline 21 & Methyl- $\alpha \mathrm{D}$-glucopyranoside & + & 46 & L-arabitol & - \\
\hline 22 & $\mathrm{~N}$-acetylglucosamine & + & 47 & Potassium gluconate & - \\
\hline 23 & Amygdaline & + & 48 & Potassium 2 ketogluconate & - \\
\hline 24 & Arbutine & + & 49 & Potassium 5 ketogluconate & - \\
\hline
\end{tabular}

Note: Specification $(+)$ = fermentable; $(-)=$ nonfermentable

\section{In Vitro Test for Cholesterol-lowering Activity}

Top ten isolates with the highest precipitation zone diameters were determined for cholesterol-lowering activity. The cholesterol-lowering test of the isolates was investigated upon incubation with $100 \mu \mathrm{g} / \mathrm{mL}$ watersoluble cholesterol-Tween 80 in MRS. Compared to the results of BSH enzyme activity, the higher precipitation zone providing opportunities to the higher cholesterol reduction activity, but it was not always linear with the results from this study. Isolates with the greatest precipitation zone (AKU-4) did not show the highest activity in the cholesterol-lowering test, while AKK-30 which had smaller precipitation zone than AKU-4 produced the highest cholesterol-lowering activity. This discrepancy might be due to different cholesterol-lowering mechanisms in each test.

There are several mechanisms of LAB in lowering cholesterol. LAB will produce the BSH enzyme which played a role as an anti-cholesterol. BSH enzyme catalyzed a reaction in which glycine and taurine were deconjugated from bile salts. The corresponding unconjugated bile acids precipitate at low $\mathrm{pH}$, which can not be reabsorbed by liver in the cycle of enterohepatic (Seeley et al., 2000) so it is excreted in the feces, resulting in reduced cholesterol levels (Huang et al., 2013).

\section{Identification of Selected LAB with the Highest Cholesterol-Lowering Activity}

The selected LAB isolate was identified based on biochemical procedures by using API $50 \mathrm{CHL}$ kit (bioMerieux) as shown in Table 4. In biochemical identification, AKK-30 isolate was identified as L. plantarum (92.3\% of similarity), and 27 types of carbohydrates were able to be fermented.

Characterization of LAB was based on 16S rRNA sequences analysis to determine the genus and strain. This gene was amplified using universal primer $27 \mathrm{f}$ and 1492 r, and the amplification result was shown in Figure 2. PCR product of $16 \mathrm{~S}$ rRNA gene was $1500 \mathrm{bp}$.

BLAST homology of $16 \mathrm{~S}$ rRNA sequences in NCBI site revealed that AKK-30 isolate was identified as L. plantarum with a length of $1414 \mathrm{bp}$ in DNA bank database (NCBI) had 100\% of max identity, 2612 of the max score, 2612 of the total score, $100 \%$ of query coverage, and 0.0 of E-value. The bacteria were classified in Kingdom of Bacteria, Division of Firmicutes, Class of Bacilli, Order of Lactobacillales, Family of Lactobacillaceae, Genus of Lactobacillus, and Species of L. plantarum. According to Stackebrandt \& Ebers (2006), when the similarity percentage of $16 \mathrm{~S}$ rRNA gene sequence between 2 organism was less than $98.7 \%-99.0 \%$, then both of them was different species. 
Phylogenetic analysis of AKK-30 isolate by nucleotide reference from Gen Bank data in NCBI was shown in Figure 3. Branch lengths are proportional to genetic distances (Becher et al., 1997). Bootstrap values of over $70 \%$ is shown for 1,000 replicate datasets (Coenye \& Vandamme, 2003). The tree describes the relationship between selected sequences retrieved from the GenBank database and nucleotide sequences in this study. The phylogenetic tree showed that L. plantarum AKK-30 isolated from Indonesian native chicken was closely

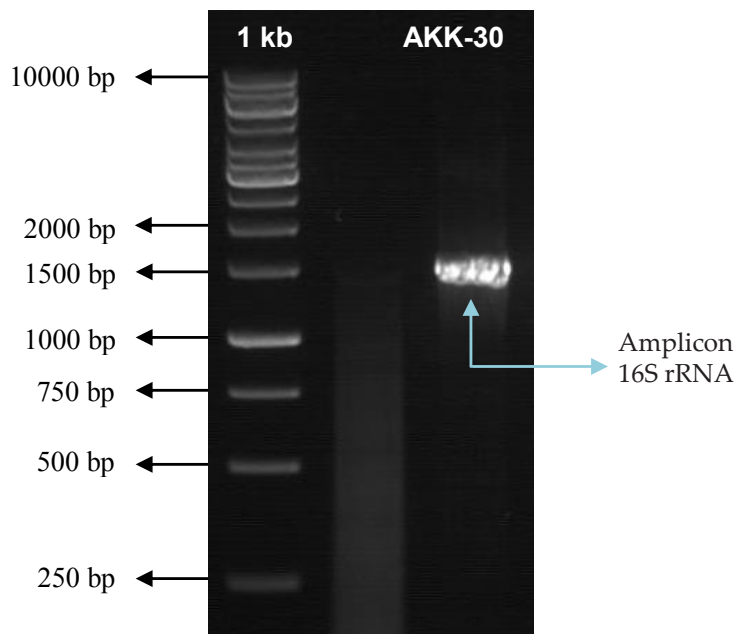

Figure 2. PCR Product $16 \mathrm{~S}$ rRNA of AKK-30 isolate and DNA ladder (1 kb DNA ladder) related to L. plantarum strain LGFCP4 isolated from GIT of Guinea fowl from India. Gong et al. (2007) stated that microbial ecology of chicken intestinal, as well as the diversity, phylogeny, distribution, and success of the bacteria as well as bird age, diet, and managing of dietary antibiotics affect the microbiota composition in these two GI tract regions. The complexity and diversity of the community structure of cecal bacteria were much higher than that of reported by culture-based studies. Moreover, a significant number of $16 \mathrm{~S}$ rRNA genes isolated from cecal microbiota were also found to be related to uncultured bacteria identified in human feces and the intestine of other animals (including ruminants, pigs, and mice).

\section{CONCLUSION}

Lactic acid bacteria isolated from the gastrointestinal tract of native chicken had the cholesterol reductase activity with various percentages. Bile salt hydrolase activity qualitatively was shown by precipitation zone around LAB colonies, while quantitatively cholesterol reductase activity indicated by the ability of lactic acids bacteria to assimilate cholesterol. The highest percentage of cholesterol reduction was shown by bacteria isolated from the colon of native chicken with the value of $17.43 \%$ and identified as L. plantarum. Based on phylogenetic tree analysis, this isolate was closely related to L. plantarum strain LGFCP4 (accession number KM199683.1) isolated from GIT of Guinea fowl from India. It could be concluded that L. plantarum AKK-30 had cholesterol-lowering activity.

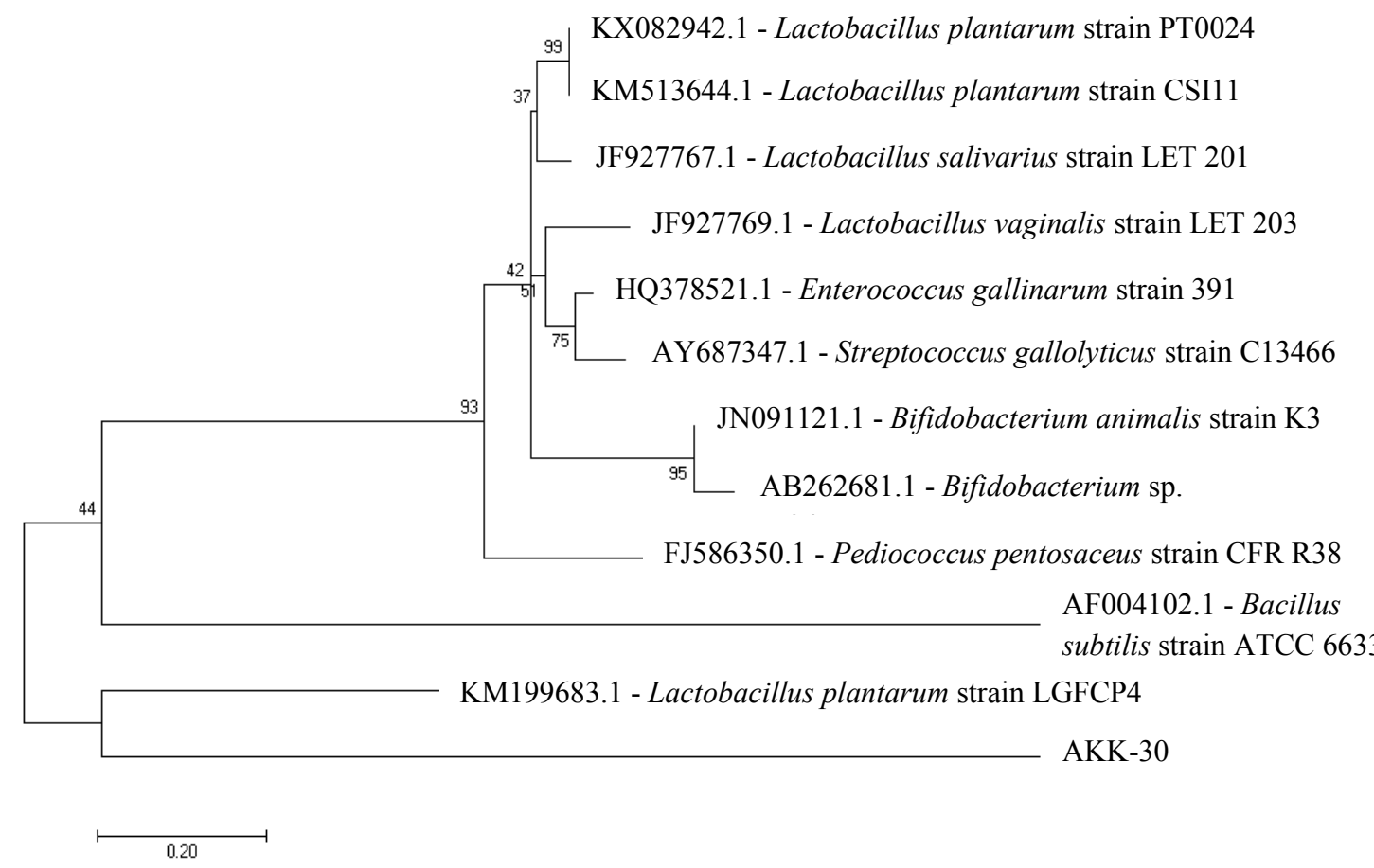

Figure 3. Phylogenetic tree of AKK-30 isolate and bacteria in the chicken's GIT constructed by a neighbor-joining method. The scale bar represents a sequence divergence of $5 \%$. 


\section{REFERENCES}

Adams, M. R. \& R. Nout. 2001. Fermentation and food safety. Aspen Publishers, Washington DC.

Agaliya, P. J. \& K. Jeevaratnam. 2012. Screening of Lactobacillus plantarum isolated from fermented idli for probiotics properties. Afr. J. Biotechnol. 11: 12856-12864.

Becher, P., M. Orlich, A. D. Shannon, G. Horner, M. KÖnig, \& H. J. Thiel. 1997. Phylogenetic analysis of pestiviruses from domestic and wild ruminants. J. General Virol. 78: 1357-1366. https://doi.org/10.1099/0022-1317-78-6-1357

Cenesiz, S., H. Yaman, A. Ozcan, \& G. Karademr. 2008. Effect of kefir as probiotic on serum cholesterol, total lipid, aspartate amino transferase and alanina amino transferase activities in broiler chicks. Med. Weter. 64:168-170

Cobos, M. A., A. L. de Coss, N. D. Ramirez, S. S. Gonzales, \& R. F. Cerrato. 2011. Pediococcus acidilactici isolated from the rumen of lambs with rumen acidosis, 16S rRNA identification and sensibility to monensian and lasalocid. Res. Vet. Si. 90: 26-30. https://doi.org/10.1016/j.rvsc.2010.05.006

Coenye, T. \& P. Vandamme. 2003. Extracting phylogenetic information from whole-genome sequencing projects: the lactic acid bacteria as a test case. Microbiology 149: 35073517. https://doi.org/10.1099/mic.0.26515-0

Damayanti, E., H. Herdian, M. Angwar, A. Febrisiantosa \& L. Istiqomah. 2012. Lactic acid bacterial screening from gastrointestinal digestive tract of native broiler chicken for probiotic candidate purposes. J. Indonesian Trop. Anim. Agric. 37: 168-175. https://doi.org/10.14710/ jitaa.37.3.168-175

de Ross, N. M. \& M. B. Katan. 2000. Effect of probiotic bacteria on diarhea, lipid metabolism, and carcinogenesis: A review of paper published between 1988 and 1998. American Journal of Clinical Nutrition. 71: 405-411.

Guo, L-D., L-.J Yang, \& G-C. Huo. 2011. Cholesterol removal by Lactobacillus plantarum isolated from homemade fermented cream in inner Mongolia of China. Czech J. Food Sci. 29: 219-225.

Gong, J., W. Si, R. J. Foster, R. Huang, H. Yu, Y. Yin, C. Yang, \& Y. Han. 2007. 16S rRNA Gene-based analysis of mucosa-associated bacterial community and phylogeny in the chicken gastrointestinal tracts: from crops to ceca. FEMS Microbiol. Ecol. 59: 147-157. https://doi. org/10.1111/j.1574-6941.2006.00193.x

Harimurti, S., E. S. Rahayu, Nasroedin, \& Kurniasih. 2005. Bakteri asam laktat dari intestin ayam sebagai agensia probiotik. Anim. Prod. 9: 82-91.

Heravi, R. M., H. Kermanshahi, M. Sankian, M. R. Nassiri, A. H. Moussavi, L. R. Nasiraii, \& A. R. Varasteh. 2011. Screening of lactobacilli bacteria isolated from gastrointestinal tract of broiler chickens for their use as probiotic. African J. Microbiol. Res. 5: 1858-1868.
Huang, Y., X. Wang, J. Wang, F. Wu, Y. Sui, L. Yang, \& Z. Wang. 2013. Lactobacillus plantarum strains as potential probiotic cultures with cholesterol-lowering activity. J. Dairy Sci. 96: 2746-2753. https://doi.org/10.3168/jds.2012-6123

Ismoyowati, I. \& T. Widiyastuti. 2003. Fat and cholesterol content of breast and thigh meat of local fowls. J. Animal Production 5: 79-82.

Jannah, S. N., A. Dinoto, K. G. Wiryawan, \& I. Rusmana. 2014. Characteristics of lactic acid bacteria isolated from gastrointestinal tract of cemani chicken and their potential use as probiotics. Med. Pet. 37:182-189. https://doi.org/10.5398/ medpet.2014.37.3.182

Kleerebezem, M. \& J. Hugenholtz. 2003. Metabolic pathway engineering in lactic acid bacteria. Curr. Opin. Biotechnol. 14:232-237. https://doi.org/10.1016/S0958-1669(03)00033-8

Krieg, N. R., J. T. Staley, D. R. Brown, B. P. Hedlund, B. J. Paster, N. L. Ward, W. Ludwig, \& W. B. Whitman. 2010. Bergey's Manual of Systematic Bacteriology. $2^{\text {nd }}$ Ed. Springer, USA.

Kumar, M., R. Nagpal, R. Kumar, R. Hemalatha, V. Verma, A. Kumar, C. Chakraborty, B. Singh, F. Marotta, S. Jain, \& H. Yadav. 2012. Cholesterol-lowering probiotics as potential biotherapeutics for metabolic diseases. Experimental Diabetes Research. Vol. 2012: 1-14. https:// doi.org/10.1155/2012/902917

Lim, H. J., S. Y. Kim, \& W. K. Lee. 2004. Isolation of lactic acid bacteria from human intestine for probiotic use. J. Vet. Sci. 5: 391-395.

Ooi, L. G. \& M. T. Liong. 2010. Cholesterol-lowering effects of probiotics and prebiotics: a review of in vivo and in vitro findings. Int. J. Mol. Sci. 11: 2499-2522. https://doi. org/10.3390/ijms11062499

Seeley, R. R., D. S. Trent, \& T. Philip. 2000. Anatomy and Physiology. $7^{\text {th }}$ ed. McGraw-Hill Co, New York.

Shazali N., H. L. Foo, T. C. Loh, D. W. Choe, \& R. A. Rahim. 2014. Prevalence of antibiotic resistance in lactic acid bacteria isolated from the faeces of broiler chicken in Malaysia. Gut Pathogens 6: 1-7. https://doi.org/10.1186/1757-4749-6-1

Sirilun, S., C. Chaiyasut, D. Kantachote, \& P. Luxananil. 2010. Characterisation of non human origin probiotic Lactobacillus plantarum with cholesterol-lowering property. African J. Microbiol. Res. 14: 994-1000.

Stackebrandt, E. \& Ebers. 2006. Taxonomic parameters revisited: "Tarnished Gold Standars". Microbiol. Today 33: 152-155.

Tomaro-Duchesneau C., M. L. Jones, D. Shah, P. Jain, A. Saha, \& S. Prakash. 2014. Cholesterol assimilation by Lactobacillus probiotic bacteria: an in vitro investigation. BioMed Res. Int. Article ID 380316, 9 pages.

Torshizi M.K., S. Rahimi, N. Mojgani, S. Esmaeilkhanian, \& J. L. Grimes. 2008. Screening of indigenous strains of lactic acid bacteria for development of a probiotic for poultry. Asian-Aust. J. Anim. Sci. 21: 1495-500. 